\title{
Yallalie: a buried structure of possible impact origin in the Perth Basin, Western Australia
}

\author{
M. C. DENTITH*, A. W. R. BEVAN†, J. BACKHOUSE \\ \& C. KOEBERLף \\ *Department of Geology and Geophysics, The University of Western Australia, Western Australia 6907, Australia \\ $\dagger$ Department of Earth and Planetary Sciences, Western Australian Museum, Perth, Western Australia 6000, Australia \\ †Geological Survey of Western Australia, 100 Plain Street, E. Perth, Western Australia 6004, Australia \\ $\S$ Department of Surveying and Land Information, Curtin University of Technology, Western Australia 6000, Australia \\ IInstitute of Geochemistry, University of Vienna, Althanstrasse 14 A-1090 Vienna, Austria
}

(Received 16 February 1998; accepted 12 March 1999)

\begin{abstract}
An enigmatic buried structure, located in Mesozoic sedimentary rocks in the Perth Basin, Western Australia, was discovered in 1990 by Ampol Exploration. The basin-like Yallalie structure (centred on $30^{\circ} 26^{\prime} 40.3^{\prime \prime} \mathrm{S}, 115^{\circ} 46^{\prime} 16.4^{\prime \prime} \mathrm{E}$ ) is circular in plan view and about $12 \mathrm{~km}$ in diameter. Highresolution, seismic-reflection profiles across the structure show a basin-shaped area of chaotic reflections that extend to a depth of approximately $2 \mathrm{~km}$ below the surface. The structure has sharp boundaries with surrounding faulted, but otherwise relatively undisturbed, rocks. In the centre of the structure there is an uplifted area approximately $3-4 \mathrm{~km}$ across, similar to those described from complex meteorite impact structures. The seismically defined structure coincides with a circular topographic depression, and image processing of digital elevation data has allowed recognition of concentric and radial structures extending as far as $40 \mathrm{~km}$ from the centre of the depression. Gravity surveys show the structure to be associated with a positive gravity anomaly of about $30 \mathrm{gu}$. Aeromagnetic surveys have defined annular anomalies associated with the central uplifted section, and possibly margins, of the structure. A search for siderophile element enrichments (by neutron activation analysis) in the rocks of the structure, which would indicate the presence of a meteorite component, proved negative. Quartz grains in cores that penetrate the structure show the development of prismatic cleavage fractures and irregular, slightly curved planes formed by brittle fracture. An allochthonous breccia of Late Cretaceous rocks occurs a few kilometres west of the western margin of the structure. Quartz grains from a thin veneer of Tertiary sediments that drape the structure are essentially undeformed. However, multiple sets of closely spaced planar deformation features in quartz, characteristic of highly shocked rocks, have yet to be observed in the rocks of the Yallalie structure and the allochthonous breccia. The morphology of the Yallalie structure determined from topographic and geophysical data suggests strongly that it is of impact origin. Geological and geochemical evidence is equivocal, but is not inconsistent with this interpretation.
\end{abstract}

\section{Introduction}

In recent years, impact cratering has been recognized as an important, but largely overlooked, geological process in the Earth's history (Melosh, 1989; Grieve, 1991). To date, some 160 impact craters ranging from a few tens of metres to several hundred kilometres in diameter, and from Recent to more than $2 \mathrm{Ga}$ in age, have been recorded throughout the world (e.g. Koeberl \& Anderson, 1996). Through the recognition of diagnostic shock-metamorphic effects in target rocks, advances in satellite imagery, and extensive geophysical surveying, the number of impact craters known has more than doubled in the last twenty years (Grieve, 1991; Pilkington \& Grieve, 1992; Grieve \& Pilkington, 1996). However, in many cases the recognition of such structures is hindered by the fact that geological processes have modified or partially destroyed the

$†$ †uthor for correspondence: bevana@museum.wa.gov.au impact record. Also, the structures may be concealed by younger strata. Grieve \& Pilkington (1996) note that approximately $30 \%$ of known terrestrial impact craters are buried beneath post-impact sediments.

Currently, some 23 structures in Australia have been recognized to varying degrees of certainty as the result of asteroidal or cometary impact (Shoemaker \& Shoemaker, 1988; Grieve, 1991; Glikson, 1996). On the basis of cratering rates through geological time, determined from dated structures throughout the world, the late E. M. Shoemaker (E. M. Shoemaker, pers. comm., 1989) predicted that perhaps as many as 15-20 additional impact structures $>10 \mathrm{~km}$ in diameter remain to be identified in Australia.

In late 1990, Ampol Exploration (now part of Mobil Exploration and Producing Australia Pty Ltd) drew the attention of the senior author to an enigmatic sub-surface structure located in Mesozoic rocks in the Perth Basin, about $200 \mathrm{~km}$ north of Perth, Western Australia. The company suspected the 
structure to be of impact origin (Dentith, Bevan \& McInerney, 1992). Recognizing an anticlinal closure beneath the structure as a possible petroleum trap, Ampol Exploration carried out intensive geophysical surveys in the area, and subsequently drilled a well (Yallalie-1) to test the structure. The well proved to be dry. Generously, Ampol Exploration have made their exploration data available for a more detailed study of the Yallalie structure. Of particular significance is the large amount of geophysical data available, including multiple lines of high-resolution seismic-reflection data, gravity and aeromagnetic surveys and complete suites of well logs from two exploration wells. In this paper, we discuss the origin of the Yallalie structure, and report geomorphological, petrological, and initial interpretations of geophysical data that support an impact origin.

\section{Geology and regional setting}

The Yallalie structure is located approximately $30 \mathrm{~km}$ northwest of the town of Moora, in Western Australia (Figs 1, 2). Geologically, the structure occurs in Mesozoic sediments of the Perth Basin adjacent to Archaean rocks of the Yilgarn Craton.

The Perth Basin is a major rift basin comprising a series of depositional troughs and basement highs. The basin lies to the west of the Darling Fault, a major structural feature approximately $1000 \mathrm{~km}$ in length and with a westerly throw of more than $10 \mathrm{~km}$. The Yallalie structure lies within the Dandaragan Trough, a north-south trending depocentre within the on-shore part of the Perth Basin, containing a thick $(>25 \mathrm{~km})$ succession of Phanerozoic fluvial, lacustrine and marine sediments.

Rifting associated with the initiation of separation of Gondwana, next to what is now the Perth Basin, occurred during the Late Permian. Marine and nonmarine sediments were deposited in the resulting intracratonic depositional basin. During the Early Triassic, a marine transgression occurred in the northern Perth Basin, while continental sedimentation continued in the southern part of the Basin and gradually spread northwards. During Middle to Late Triassic times, fluvial sedimentation prevailed throughout the Perth Basin. A succession of fluvial sediments and coal swamp deposits of Early Jurassic age conformably overlies the Triassic. A brief marine transgression followed, with the deposition of shallow marine shales, siltstones, and sandstones of the Cadda Formation (approximately Bajocian) in the northern Perth Basin. The subsequent regressive phase resulted in the extensive deposition of up to $3 \mathrm{~km}$ of fluvial sandstones, siltstones and shales of the Yarragadee Formation (approximately Middle to Late Jurassic) throughout the Perth Basin.

The succeeding Parmelia Formation (approximately late Tithonian to Berriasian) conformably overlies the Yarragadee Formation. The basal member of the Parmelia Formation is a thin, but laterally extensive, lacustrine to lagoonal sequence termed the Otorowiri Member. This member is always present at the base of

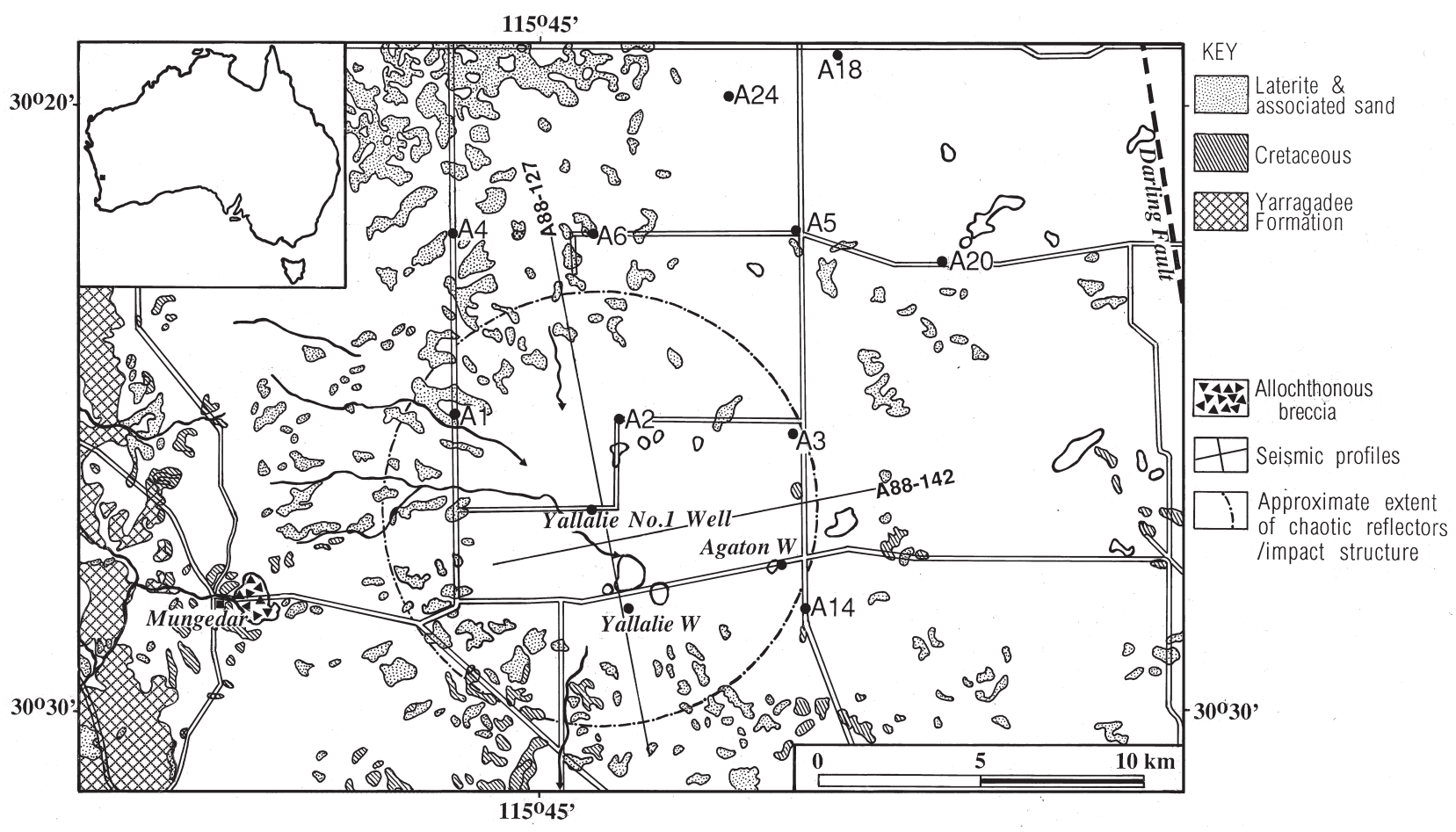

Figure 1. Location and geological (drift) map of the Yallalie structure, Western Australia. A88-127 and A88-142 are the seismic lines for the profiles shown in Figures 7 and 8, respectively. 
the Parmelia Formation, where it is preserved in areas of the Dandaragan Trough and adjacent Vlaming Sub-basin (Backhouse, 1984). The rest of the Parmelia Formation represents a return to fluvial sedimentation with considerable lacustrine deposition. The Carnac Member of the Parmelia Formation is a thick claystone sequence that was deposited, at least partly, in large lakes or inland seas. The greater part of the Parmelia Formation, as it occurs in the Dandaragan Trough, is represented by the Otorowiri and Carnac members.

Best estimates of the age of break-up of Gondwana adjacent to the Perth Basin, as expressed by the major episode of faulting and subsidence, put it at approximately early Valanginian. Major faulting resulted in a half-graben-style basin architecture with numerous strike-slip faults and structural relief of thousands of metres (Spring \& Newell, 1993). Many hundreds of metres of the then recently deposited Early Cretaceous sediments were stripped off during subsequent rapid erosion. Subsidence of the continental margin and probably rising sea level allowed a marine transgression and deposition of the Warnbro Group (Valanginian to Aptian). In the Dandaragan Trough, glauconitic marine beds are developed in the uppermost part of the Leederville Formation (Warnbro Group), corresponding to the Muderongia australis Zone of the dinoflagellate cyst zonation of Helby, Morgan \& Partridge (1987).

In the central Dandaragan Trough, a lacuna exists between the top of the Leederville Formation and the overlying Coolyena Group. In this area, the base of the Coolyena Group is a marine glauconitic claystone, no older than Endoceratium ludbrookiae Zone (dinoflagellate cyst), of mid Albian age. Younger units of the Coolyena Group indicate the existence in this part of the basin of shallow marine shelf conditions during the Late Cretaceous. As in other regions, the close of the Maastrichtian is marked by a regression. Intermittent deposition has occurred in the Dandaragan Trough throughout the Cenozoic with shallow marine deposits in some coastal areas, and Pleistocene-Holocene aeolian, colluvial and alluvial deposits (Cockbain, 1990). The major period of lateritization in the Perth Basin probably occurred during the mid Tertiary (Hocking, Moors \& van de Graaff, 1987).

\section{Previous geological investigations in the Yallalie area}

Regional geological mapping of the Yallalie area (Playford, Cockbain \& Low, 1976) recognized a small but conspicuous structure, believed to be anticlinal, that has been alternately called the 'Muthawandery Structure' or 'Muthawandery Anticline.' Exploratory drilling on the Watheroo line of the Agaton Borefield Project (see below), some $22 \mathrm{~km}$ north of the structure, has shown that a gentle anticlinal structure developed in the Yarragadee Formation. Playford, Cockbain \& Low (1976) suggested that the Muthawandery Structure may be a southern termination of the same anticlinal trend. However, they concluded that the origin of the structure is unknown.

In the late 1960s, as part of an investigation of the groundwater resources of the Perth Basin, boreholes were sunk in the Watheroo area. The Agaton Exploratory Borefield Project was named after a prominent spring in the south of the exploration area, situated near the eastern edge of the Yallalie structure. In all, boreholes were drilled at 28 sites for a total of $15258 \mathrm{~m}$ drilling (Passmore, 1969; W. P. Balleau \& J. R. Passmore, unpub. report, Geological Survey of Western Australia, 1972/11). Conventional rotary cores were cut at $61 \mathrm{~m}(200 \mathrm{ft})$ intervals in the main borehole at each site. Eleven boreholes (Fig. 1) were drilled in and around the area of the Yallalie structure. Unfortunately, material from only seven of these bores is preserved and is currently housed in the core library of the Geological Survey of Western Australia.

Passmore (1969) noted that the potentiometric surface in the Watheroo area to the north of the Yallalie structure indicated that the groundwater moves southeastwards to within $7-10 \mathrm{~km}$ of the Darling Fault and is then deflected sharply to the southwest along a narrow zone through the Agaton spring region. Passmore (1969) suggested that this is the result of water entering the aquifers close to the Darling Fault, and Balleau \& Passmore (W. P. Balleau \& J. R. Passmore, unpub. report, Geological Survey of Western Australia, 1972/11) concluded that most of the groundwater outflow passes through a 'structural trough' in the Yarragadee Formation (the upper part of which is now included in the Parmelia Formation) below the Yallalie basin. However, these researchers did not elaborate on the nature or origin of the structure.

More recently, high-resolution seismic profiles across the Yallalie structure have revealed a basinshaped zone, about $12 \mathrm{~km}$ in diameter, characterized by chaotic reflections. This is interpreted as due to intensely disturbed rocks that must extend down to a depth of approximately $1.5 \mathrm{~km}$ below the surface. Below the structure is a domal uplift apparently free from faulting, which directly underlies the zone of chaotic reflectors. The Yallalie-1 exploration well was drilled to test this uplift. The well was sunk to a total depth of $3321.8 \mathrm{~m}$. No rotary cores were recovered. However, ditch cuttings were taken at $5 \mathrm{~m}$ intervals from $27 \mathrm{~m}$ to total depth. Additionally, sidewall cores were taken at regular intervals from $57 \mathrm{~m}$ to $3318 \mathrm{~m}$. The stratigraphy of the well was determined by palynology in terms of zonal schemes presented by Helby, Morgan \& Partridge (1987) and Backhouse (1988). These allow a reasonably tight correlation between wells in the Dandaragan Trough, dependent on the number of core sample points. Wireline logs are used to pick formation boundaries within the constraints of 
palynological determinations. The stratigraphy of the well is amended slightly for this paper, and is shown in Figure 3, correlated with the stratigraphy in nearby areas of the Dandaragan Trough.
The log of the Yallalie-1 well shows several variations from those predicted by the regional stratigraphy. At depths of between 66 and $177 \mathrm{~m}$, Pliocene lacustrine sediments were encountered representing

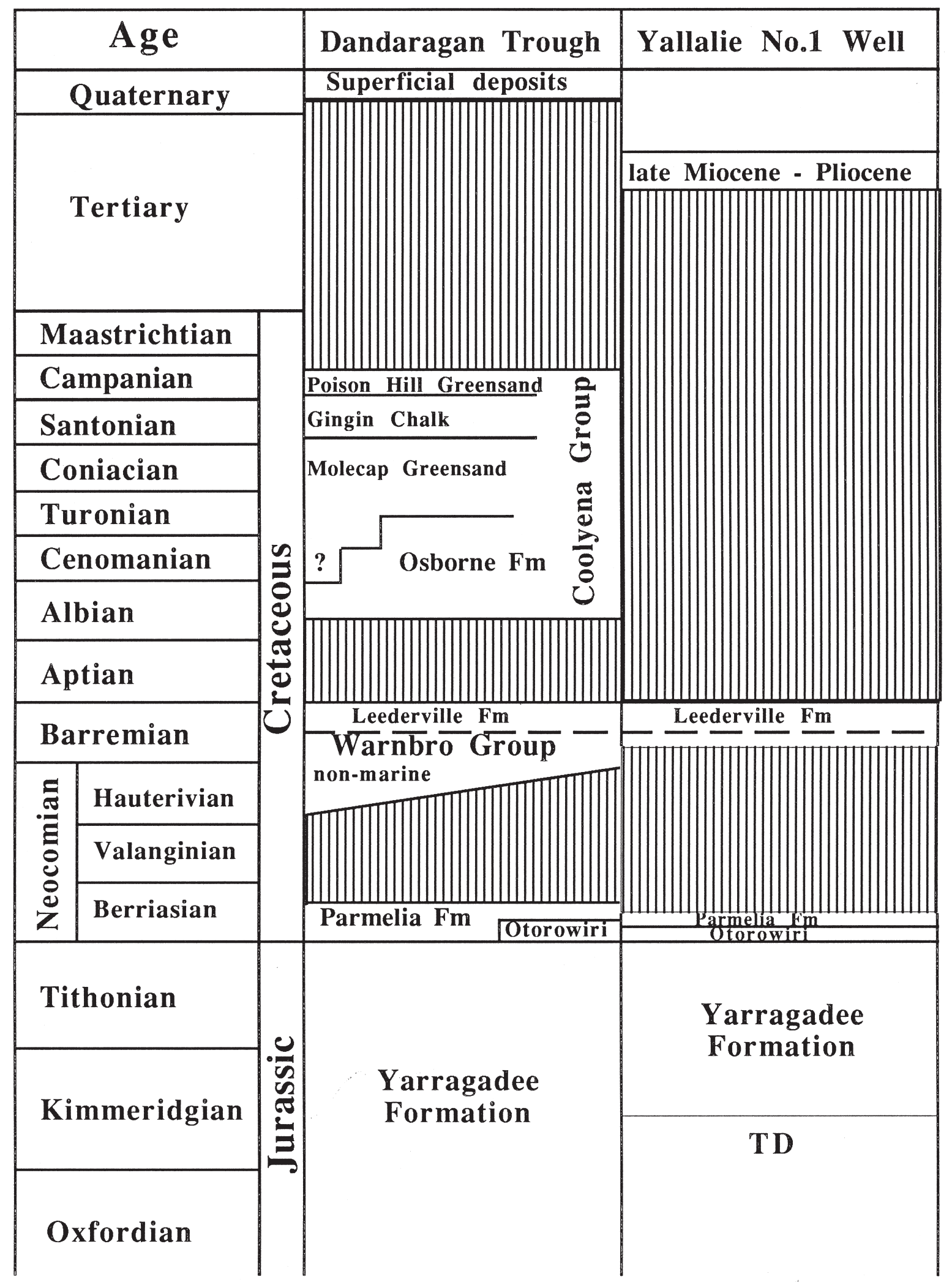

Figure 3. Stratigraphy of the Yallalie-1 well correlated with that of the adjacent Dandaragan Trough. 
the first known occurrence of such a unit in the onshore Perth Basin, and only the second occurrence identified in Western Australia. Although the Leederville Formation (Barremian) was not expected to occur in the well, $62 \mathrm{~m}$ was drilled directly below an angular Tertiary/Cretaceous unconformity at $177 \mathrm{~m}$ depth. A distinctive colour change in the claystones was noted across the Tertiary-Cretaceous unconformity from dark grey to light grey or cream, indicative of a period of weathering or leaching. The Leederville Formation lies unconformably on the Parmelia Formation encountered between 239 and $312 \mathrm{~m}$. The basal Otorowiri Member of the Parmelia Formation, identified from wireline logs, is picked between 270 and $312 \mathrm{~m}$. The Parmelia Formation proved to be thinner than predicted, although because the palynological control is poor, owing to the lack of sufficient sample points, the stratigraphy of the well is tenuous at this level. The remainder of the well (320-3321.8 m) penetrated the upper part of the Yarragadee Formation (Aequitriradites acusus-Murospora florida spore-pollen zones). The base of the zone of chaotic seismic reflectors was encountered at $1562 \mathrm{~m}$. Comparison of time/depth plots between Yallalie-1 and nearby wells indicated up to $700 \mathrm{~m}$ uplift of previously more deeply buried sediments (M. Economo, unpub. report, Ampol Exploration Ltd. 1991).

Quartz grains from sandstones of the Yarragadee Formation at depths of $430-460 \mathrm{~m}$ in the Yallalie-1 well (V. A. Gostin, pers. comm. 1990) show unusual deformation features. In his report to Ampol, Gostin noted that quartz grains displayed prismatic cleavage and irregular curved planes formed essentially by brittle fracture. No evidence was found in the samples of multiple sets of closely spaced planar features indicative of intense shock deformation that would have provided definitive evidence of meteorite impact. Gostin concluded that the deformation features corresponded to the first class of fractures described from the least deformed rocks of other impact craters, but that the scale of deformation did not provide conclusive evidence of an impact origin (K. B. McInerney, unpub. honours thesis, Univ. Western Australia, 1991). Moreover, the samples were taken from sidewall cores that were removed explosively.

\section{Surface morphology and digital elevation modelling}

The exposed geology of the general area around the Yallalie structure comprises discontinuous sequences of variably weathered sandstones, siltstones and shales of assumed Middle Jurassic to Late Cretaceous age. These are capped by laterite and are locally covered by thin $(<50 \mathrm{~m})$ Tertiary and Quaternary aeolian, colluvial and alluvial deposits (Cockbain, 1990). Although the underlying structure of intensely disturbed rocks is 'draped' by a thin veneer of later sediments, it has some surface expression. A broad depression approxi- mately $120 \mathrm{~m}$ deep is bounded to the west and north by a marked divide (Fig. 4). The deepest part of the depression occurs near Yallalie Well, southeast of the centre of the structure, where there is a small ephemeral lake (Figs 1, 2). Overall, the Yallalie depression is characterized by a centripetal pattern of drainage that is gradually exhuming the buried structure. A southerly flowing stream, Muthawandery Creek, has periodically drained the depression and has breached the 'rim' to the south. The springs in the area, including the Agaton Spring, rise on or around the divide of the depression, and creeks developed on the western and northern flanks of the structure feed into the Yallalie basin.

In order to investigate further the morphological expression of the Yallalie structure, a digital elevation model of the area was constructed (Fig. 4a). An area $80 \times 80 \mathrm{~km}$, with the seismically defined structure at its centre, was analysed in the expectation that structures associated with the supposed impact would extend beyond the limits of the zone of chaotic reflectors on the seismic data.

Datasets used in the construction of the digital elevation model are listed in Table 1 . The digitized contour data and spot heights were obtained from the Western Australian Department of Land Information and the Australian Land Information Group, respectively. The reduction of gravity data requires knowledge of the elevation of the observation, and this provides a useful source of additional topographic data. Also, elevations are measured during the acquisition of seismic reflection data, so as to allow calculation of static corrections. This, too, is a useful source of elevation data. The vertical and lateral accuracy of these data varies from tens of metres to a few centimetres, depending on the type of survey method used. However, there is generally good agreement between the different datasets, and the errors are not significant in terms of the scale at which the digital elevation model is being analysed. The distribution of the elevation data is not uniform across the area of interest, with most data being available in the centre of the region where the seismic defined structure occurs (Fig. $4 c)$. This creates some problems when the data are gridded to create the digital elevation model. A cell size of $250 \mathrm{~m}$ was selected as the most appropriate, this being a compromise between resolving the maximum detail in areas of high data density, and not introducing

Table 1. Elevation data used in the construction of the digital elevation model

\begin{tabular}{lc}
\hline Data & No. of points \\
\hline Digitized topographic contours & 64258 \\
Spot heights & 3509 \\
Gravity observations & 769 \\
Elevations from seismic sections & 2168 \\
TOTAL & 70704 \\
\hline
\end{tabular}


artefacts and gaps into the grid in less well-constrained areas.

The resulting grid of topographic values was analysed using various spatial data processing and imaging techniques commonly applied to the enhancement of remote sensing and geophysical data (e.g. see Drury, 1993). The assumption was made that the topography was influenced by structures, for example faults and joints, which formed during the impact event. Radial and concentric linear and curvilinear structures were anticipated. The wavelength of the structures was not expected to be large. Thus, data processing was aimed at emphasizing relief of this type. The most effective enhancement was found to be false-sun illumination. This occurs where the effects of a light source in a given position are calculated. The resulting shadows and well-illuminated areas allow the eye to distinguish subtle features not readily apparent in other forms of data presentation, for example contouring. Because this process tends to emphasize a)

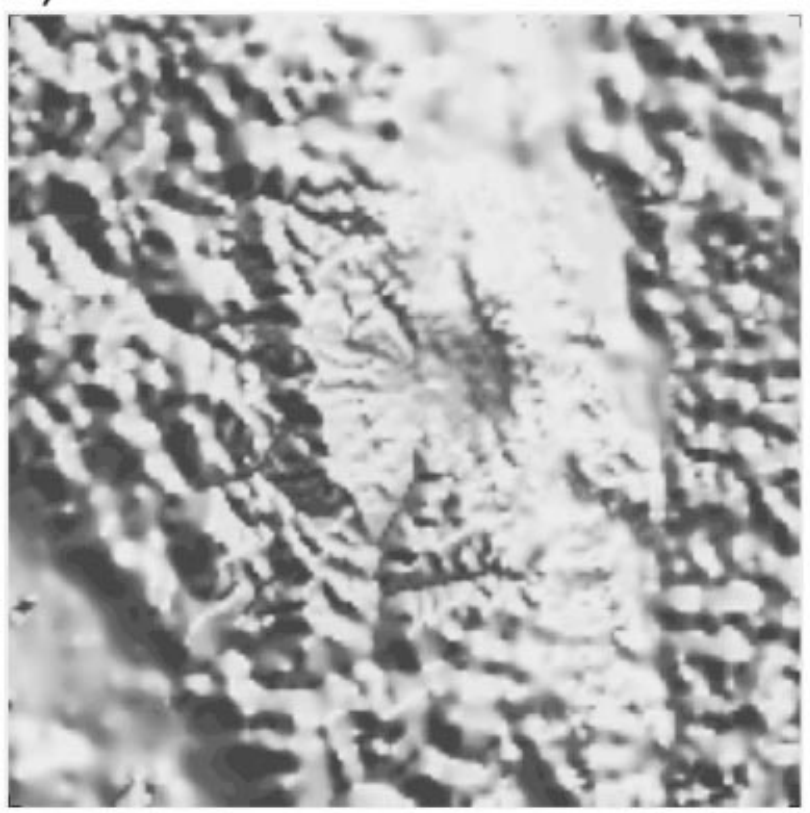

c) b)

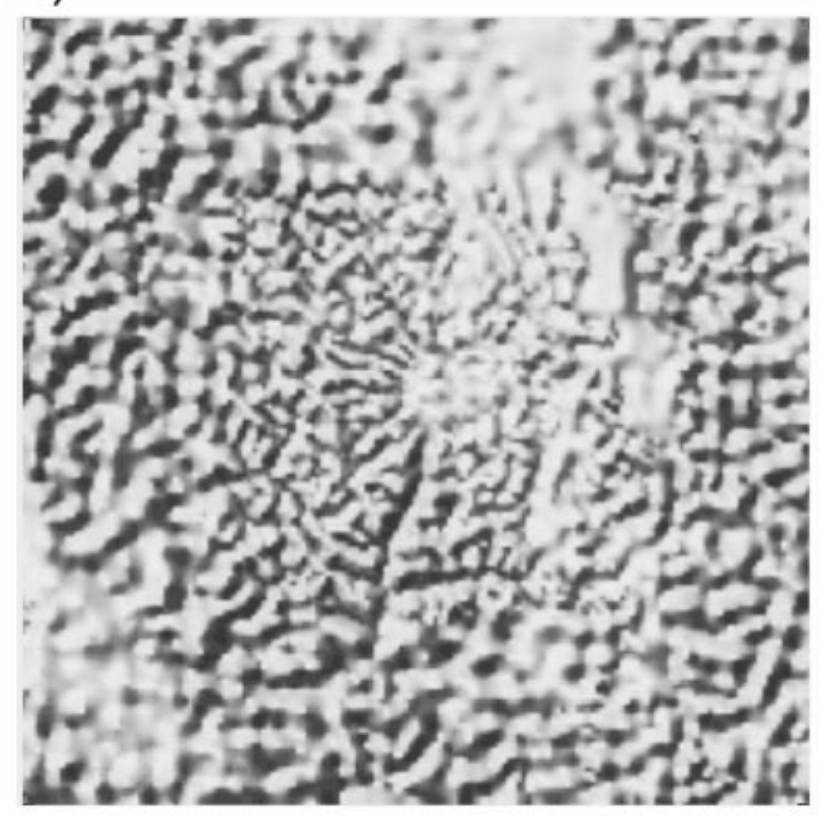

d)
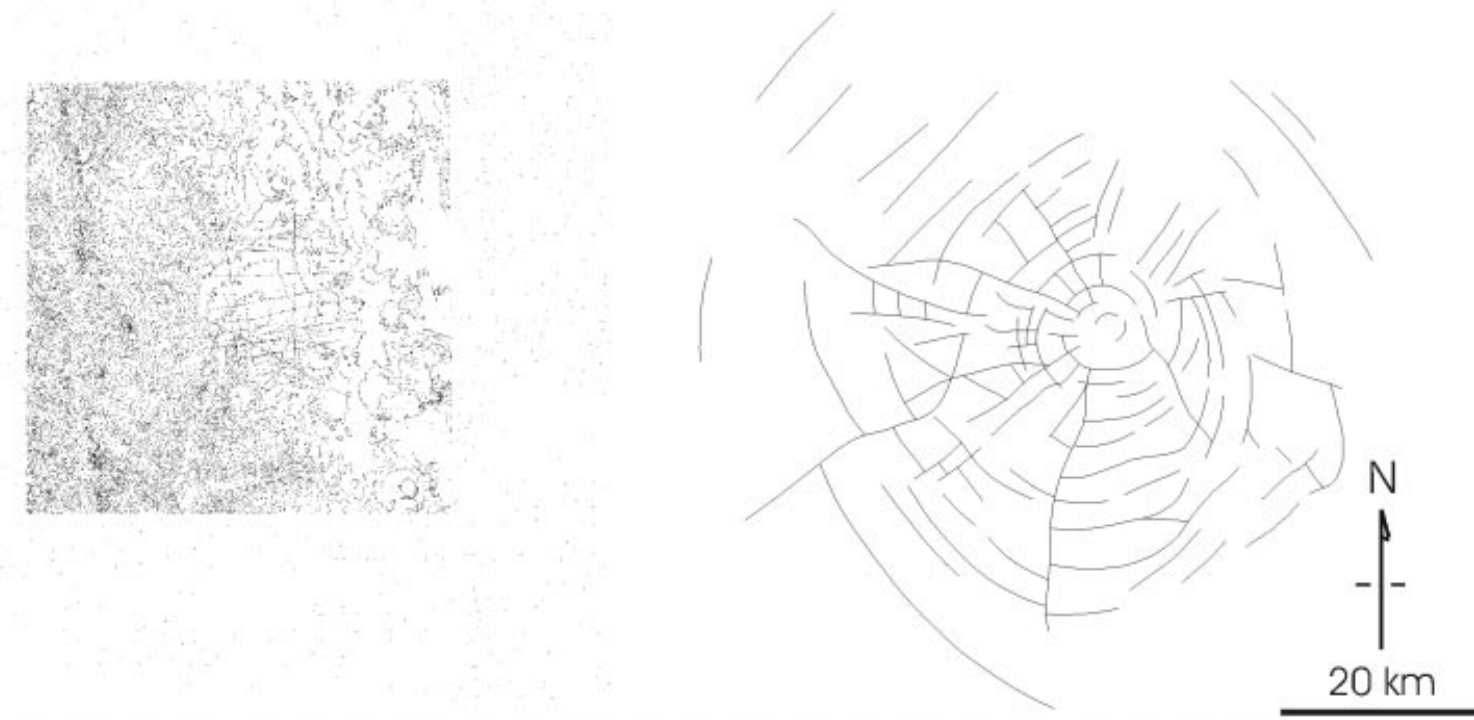

Figure 4. Digital elevation model of the Yallalie Basin and its surrounds: (a) topography, (b) topography after high-pass filtering, (c) data points, and (d) interpreted lineaments. 
features running perpendicular to the direction of illumination, a series of images was created with the source of illumination in different positions. Various high-pass wave-number filtering operations were also applied to the data to emphasize the relatively short wavelength features (such as gullies due to erosion around faults) at the expense of longer wavelength variations (i.e. caused by differential erosion of different lithologies). The resulting datasets were then also illuminated to highlight features of interest. Two of the topographic images are shown in Figures $4 \mathrm{a}$ and $4 \mathrm{~b}$, and an interpretation of these and other images is shown in Figure 4d.

The processing of the topographic data allowed recognition of numerous radial and concentric features extending as far as $40 \mathrm{~km}$ from the centre of the Yallalie structure as defined by the seismic data (Fig. $4 d)$. It is difficult to interpret the concentric features as not being related to the origin of the structure. Note that these features increase in spacing away from the centre of the structure, as is observed with faultbounded terraces in lunar craters. However, this may be a function of the decreasing resolution of the terrain model with distance from its centre. The outermost concentric structures are more linear than expected, and suggest a roughly square shape. This is similar to the shape of Meteor Crater in Arizona, where the shape is attributed to the effects of preimpact jointing in the target rocks (Shoemaker, 1960). The significance of the radial structures at Yallalie is less certain. These are generally deeper than the concentric structures, and are intimately related to the local drainage. Whether this is due to preferential erosion along radial faults and joints, or is simply the logical consequence of draining into a circular depression, is unknown. The presence of radial faults is supported by the fact that these sometimes terminate the concentric features. The reverse is also true, implying that both types of structures formed at the same time. Note that both types of structure are best defined to the west of the main depression. This is a function of the presence of higher ground and, hence, better developed drainage. A similar density of structures is anticipated in other areas, and no geological significance is attributed to this difference. The data also show the approximate position of the Darling Fault, which is associated with a scarp extending north-south about $15 \mathrm{~km}$ from the eastern edge of the digital elevation model. The northwest-trending feature in the southwest of the digital elevation model is a palaeoshoreline (Fig. 4a).

\section{Geophysics}

A large amount of geophysical data has been acquired at various times across the Yallalie structure and its surrounds. The region was covered by regional gravity and aeromagnetic surveys carried out by the former
Bureau of Mineral Resources (now Australian Geological Survey Organisation). Several phases of seismic reflection data were collected in the area as part of petroleum exploration programmes, although the Yallalie structure itself was only clearly imaged by surveys of 1988 vintage and later. Following the identification of the petroleum potential of the Yallalie structure, a high-resolution aeromagnetic survey was carried out over its central part, and two traverses of gravity measurements were made trending north-south and east-west across its centre. Additional gravity measurements were made subsequently by the authors. A detailed description of the processing and interpretation of the different geophysical datasets is beyond the scope of this paper and will be reported elsewhere. The major problem to be addressed is the isolation of the gravity and magnetic anomalies due to the Yallalie structure from the much larger amplitude anomalies associated with the juxtaposition of some $15 \mathrm{~km}$ of sediments within the Perth Basin and the crystalline rocks of the Yilgarn Craton. The Darling Fault, which separates these two terrains, is located only a few kilometres to the east of the Yallalie structure (Fig. 4). The geophysical response of the Yallalie structure is illustrated with data from two orthogonal traverses across its approximate centre. These traverses roughly coincide with two of the seismic-reflection profiles across the structure trending approximately north-south and east-west.

Profiles of topography, Bouguer gravity and total magnetic intensity (both surveys) are shown in Figures 5 and 6. Also shown are the extents of the 'zone of chaotic reflectors' and the central uplifted area of the Yallalie structure as defined by the seismic reflection

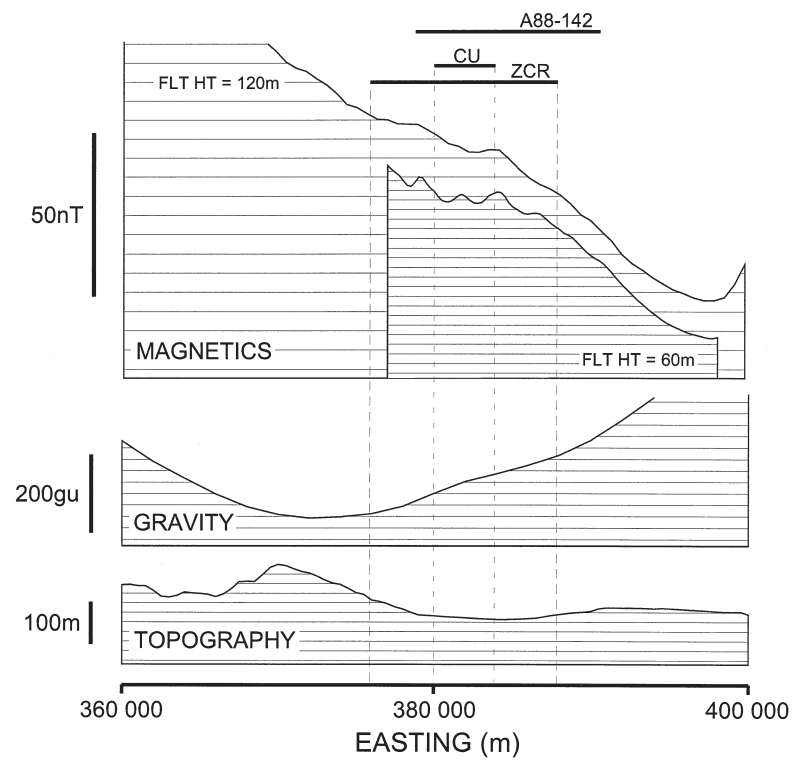

Figure 5. East-west profiles of topography, Bouguer gravity and total magnetic intensity across the centre of the Yallalie structure. A88-142 is the seismic profile shown in Figure 8. $\mathrm{CU}=$ central uplift; $\mathrm{ZCR}=$ zone of complex reflectors. 


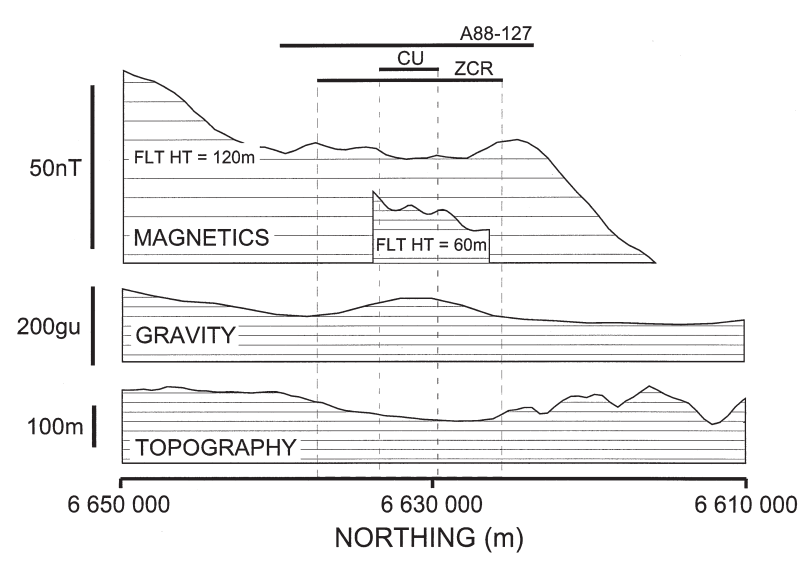

Figure 6. North-south profiles of topography, Bouguer gravity and total magnetic intensity across the centre of the Yallalie structure. A88-127 is the seismic profile shown in Figure 7. Abbreviations are for Figure 5.

data (see below). The profiles of topography clearly illustrate the bowl-shaped nature of the depression, and also the presence of higher ground to the west of the structure causing the better definition of structural elements described previously. The regional aeromagnetic survey was flown at a height of $120 \mathrm{~m}$. Poorly defined positive anomalies coincide with the margins of the central uplifted area of the Yallalie structure. Note the long wavelength increase in magnetic intensities on both profiles, probably caused by magnetic material within the basement to the Perth Basin. From the high resolution data, acquired at a height of $60 \mathrm{~m}$, anomalies associated with the centre and margins of the central uplift are clear. An anomaly may also occur at the edge of the zone of chaotic reflectors. Gridding of the entire survey shows the anomalies to be annular in plan view. Their exact cause remains uncertain, but they are certainly associated with the Yallalie structure, and may be due to the presence of magnetic impact-melt rocks or suevite breccias.

The gravity profiles illustrate the problem of identifying the effects of the Yallalie structure in the presence of the effects of the Darling Fault. The east-west profile shows a large increase in gravity to the east associated with the fault (Fig. 5). Although not completely shown on the diagram for reasons of space, this anomaly has an amplitude in excess of 1000 gu further to the east. To the west there is also an increase in gravity due to a basement high within the Perth Basin. The anomaly due to the Yallalie structure is a poorly defined positive anomaly superimposed on these larger effects. The north-south profile is more useful for identifying the gravity response of the Yallalie structure (Fig. 6). Here the effects of the Darling Fault, which trends approximately north-south, are nearly constant. The Yallalie structure is associated with a positive anomaly of amplitude, approximately $30 \mathrm{gu}$. Most impact structures are associated with negative gravity anomalies due to a decrease in density of brecciated material (Pilkington \& Grieve, 1992). Assuming an impact origin for the Yallalie structure, the positive anomaly can be shown to be the result of the deep erosion of the structure resulting in removal of much of the brecciated material, allowing the effects of relatively dense material uplifted from depth to dominate the gravity response (Dentith et al. unpub. data).

The most spectacular data from the Yallalie area are the seismic reflection profiles. A number of features are clear on the two examples shown in Figures 7 and 8. These two lines, A88-127 and A88-142, cross the Yallalie structure near its centre, trending at approximately $90^{\circ}$ to each other (Fig. 1). The Yallalie structure is seen as a bowl-shaped zone of complex reflector geometry extending to about 1.5 seconds two-waytime (TWT). In its centre is a zone approximately $3-4$ $\mathrm{km}$ in diameter of uplifted and faulted rocks similar to those described from complex impact structures (Dence, Grieve \& Robertson, 1977; Grieve, Robertson \& Dence, 1981). This gives the structure the classic sombrero-shape of a complex impact structure. The faulting in the annulus surrounding the central uplift seems to involve detachments at the margins of the uplift and the structure itself. The sharp contact with the surrounding undisturbed strata suggests the edge of the structure is some kind of fault/detachment surface. Beneath the central uplift is an area of less intense deformation, where the underlying sediments have been uplifted to form a domal structure. The possibility that this was a pull-up feature was discounted, after analysis of the velocities of the sediments above and below. Note that coherent reflections are easily traced across both sections to define this structural high. This was the target of the Yallalie-1 well. The transition from intense deformation, and thus poorly coherent reflections, to the well-defined underlying dome is abrupt, again suggesting that a detachment surface underlies the former. Overlying the central uplift and its immediate surrounds are sub-horizontal reflectors, continuing to about 0.3 seconds TWT, associated with lake sediments that fill the topographic depression.

To date, the geophysical data, particularly the seismic reflection data, provide the best indication of an impact origin for the Yallalie structure. The clear continuity of reflection events beneath the most severely deformed part of the structure unequivocally demonstrates that the cause of the structuring could not be a process originating at depth. The source of the deformation clearly came from above.

\section{Geology, petrology and geochemistry}

Samples of the outcropping rocks in the area of the Yallalie structure were collected for petrological work. In addition, some available conventional cores and ditch cuttings from the Agaton Borefield Project 


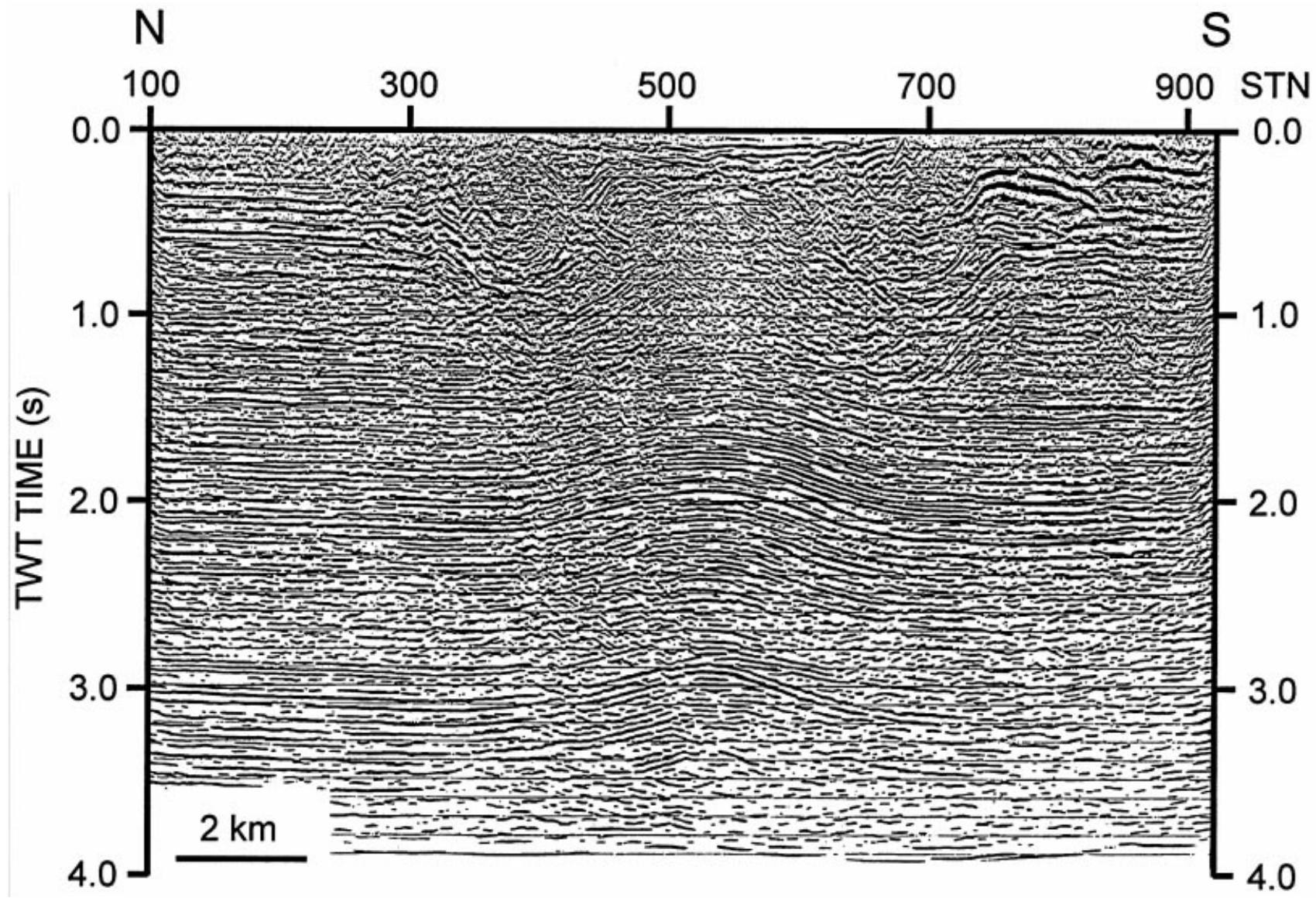

Figure 7. Migrated seismic reflection profile A88-127 across the Yallalie structure. The bowl-shaped zone of chaotic reflectors lies between station 300 and 700 and extending to about 1.5 seconds TWT. Note that continuous reflectors can be easily traced below the Yallalie structure. See Figure 1 for location.

(Passmore, 1969) were examined, and samples selected visually for geochemical and petrographic work. Unfortunately, the critical core Agaton 2 that penetrates the structure on the flank of the centrally uplifted area was not available for study. Two boreholes (Agaton 1, and Agaton 3; see Fig. 1) of the Agaton Borefield Project that penetrate the underlying structure at its margins were sampled and ten samples were examined in detail. Four core samples were analysed by Instrumental Neutron Activation Analysis (INAA) for minor and trace elements (Agaton $1 / 1200 \mathrm{ft}(365.76$ $\mathrm{m})$, Agaton $3 / 1700 \mathrm{ft}(518.1 \mathrm{~m})$, Agaton $3 / 2010 \mathrm{ft}$ $(612.6 \mathrm{~m})$, Agaton $3 / 2302 \mathrm{ft}(701.6 \mathrm{~m})$ ) at the Institute for Geochemistry, University of Vienna, following methods described by Koeberl (1993).

Covered and polished thin sections and grain mounts were made from five surface (YA 003, YA 005, YA 006, YA 015, YA 018) and six core (Agaton $1 / 1200 \mathrm{ft}$, Agaton 3/320-330 ft, Agaton 3 (core 2)/920-930 ft, Agaton 3/1060-1070 ft, Agaton 3/1600 ft, Agaton $3 / 1700 \mathrm{ft}$ ) samples. Biostratigraphic analyses of some of the recovered cores from the Agaton Borefield Project (including Agaton 3) have been reported by Backhouse (J. Backhouse, unpub. reports, Geological Survey of Western Australia, 1972/91, 1993/5, 1993/11).
A search for impact breccias, diaplectic glass and impact melts in the available core material from the Agaton boreholes was unsuccessful. Rocks from the Yallalie structure examined petrographically in this work are listed and described in Table 2. The samples from cores are mostly poorly consolidated feldspathic sandstones, siltstones and claystones. However, some of the outcropping sandstones, stripped of their laterite capping, are strongly silicified, and are more correctly described as quartzites and silcretes.

While no breccias have yet been located within the structure, reconnaissance of the area surrounding Yallalie revealed a breccia deposit (at $30^{\circ} 28^{\prime} \mathrm{S}$, $115^{\circ} 39^{\prime} 20^{\prime \prime} \mathrm{E}$; see Fig. 1) composed of fragments and blocks (ranging up to more than a metre across) of sandstone, a green coloured rock now partially weathered to clay, and a white porcellanous clay (Fig. 9). The breccia had previously been mapped as rocks of Late Cretaceous age. The breccia is external to the Yallalie structure, a few kilometres west-southwest of its western margin, and is similar in character and location to the famous 'Bunte' breccia described from the Nördlinger Ries impact structure in Germany (E. M. Shoemaker, pers. comm. 1995; Hörz, 1982; Hörz, Ostertag \& Rainey, 1983). 
Table 2. Core and surface samples selected for the study of the Yallalie structure

\begin{tabular}{llcc}
\hline Well & sample type & depth (feet) & Lab no. \\
\hline Agaton 1 & ditch cutting & 1200 & Y-1200* \\
Agaton 3 & rotary core & $320-330$ & Y-320 \\
Agaton 3 (core 2) & rotary core & $920-930$ & Y-920 \\
Agaton 3 & rotary core & $1060-1070$ & Y-1060 \\
Agaton 3 (core 11) & rotary core & $1600-1610$ & Y-1600* \\
Agaton 3 (core 12) & rotary core & 1700 & Y-1700* \\
Agaton 3 & rotary core (3) & $2000-2010$ & Y-2000 \\
Agaton 3 & rotary core & 2010 & Y-2010 \\
Agaton 3 & rotary core & 2302 & Y-2302 \\
Agaton 3 & ditch cutting & 2310 & Y-2310 \\
\hline
\end{tabular}

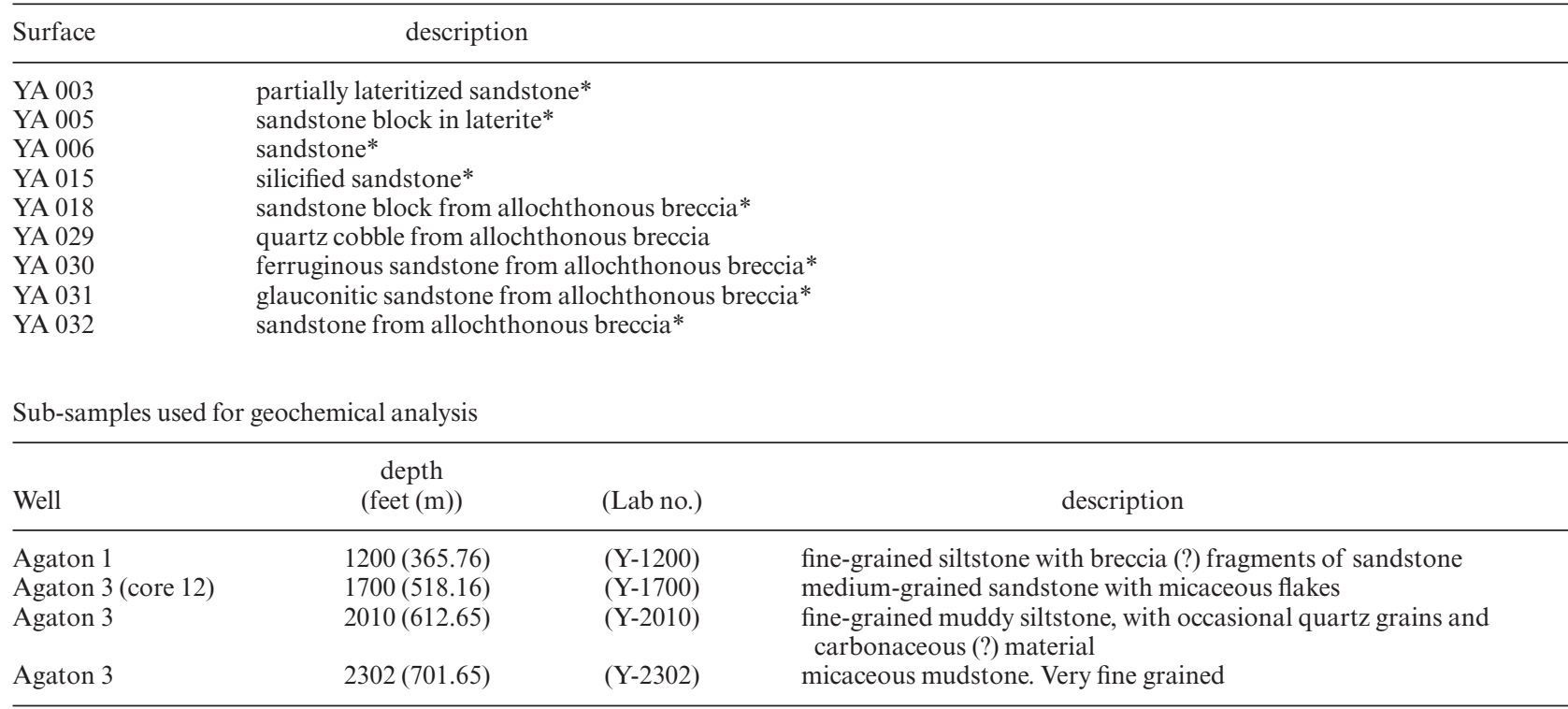

(* indicates samples from which thin sections/grain mounts were made)

Neither shatter cones nor microscopic evidence of intense shock-metamorphism has been found in any of the surface rocks or core samples studied, including rocks from the allochthonous breccia. Many grains of quartz in samples from a variety of depths show strong undulose extinction and the incipient development of multiple extinction features, although these could be attributed to causes other than shock-metamorphism. Also, occasional grains of quartz displaying incipient prismatic cleavage and brittle fracture were observed in core samples to a depth of $>600 \mathrm{~m}$. (Figs 10, 11). These deformation features correspond to the lowest levels of shock-metamorphism described from other known impact structures. However, closely spaced multiple sets of well-developed planar features in either quartz or feldspar, diagnostic of highly shocked rocks (compare Stöffler \& Langenhorst, 1994) were not observed.

In an attempt to search for siderophile element or other geochemical anomalies in the target rocks that may be indicative of meteorite impact, core samples from the Agaton Borefield in the Yallalie structure were analysed by INAA for three minor and 35 trace elements. Results for four core samples are given in Table 3. The rare-earth element (REE) abundances (Fig. 12) are typical of sedimentary rocks and show no unusual features. Siderophile element anomalies were not detected, although one sample (Y-1700) contains $0.15 \pm 0.1 \mathrm{ppb}$ Ir. However, this is at the detection limit for this element and may not be significant.

\section{Age}

The apparent lack of impact-melted rocks in the Yallalie structure severely limits the application of absolute dating techniques to constrain the age of the structure. However, upper and lower limits of the age of the structure can be determined from the stratigraphy and the occurrence of the allochthonous breccia.

The undisturbed nature and apparent absence of deformation features in quartz grains from surficial Tertiary and Quaternary sediments that overlie the Yallalie structure indicates that the formation of the structure pre-dates their deposition. The first recognizable indications of microscopic deformation in the rocks of the structure and structural evidence of disturbance occur at depths of $>239 \mathrm{~m}(784.1 \mathrm{ft})$ in the Yallalie-1 well. In the Yallalie-1 well, palynology indicates that the deformed rocks are at least of Late Jurassic to Berriasian in age (M. Economo, unpub. report, Ampol Exploration Ltd, 1991). Rocks of mid to Late Cretaceous age (Coolyena Group) that occur in 


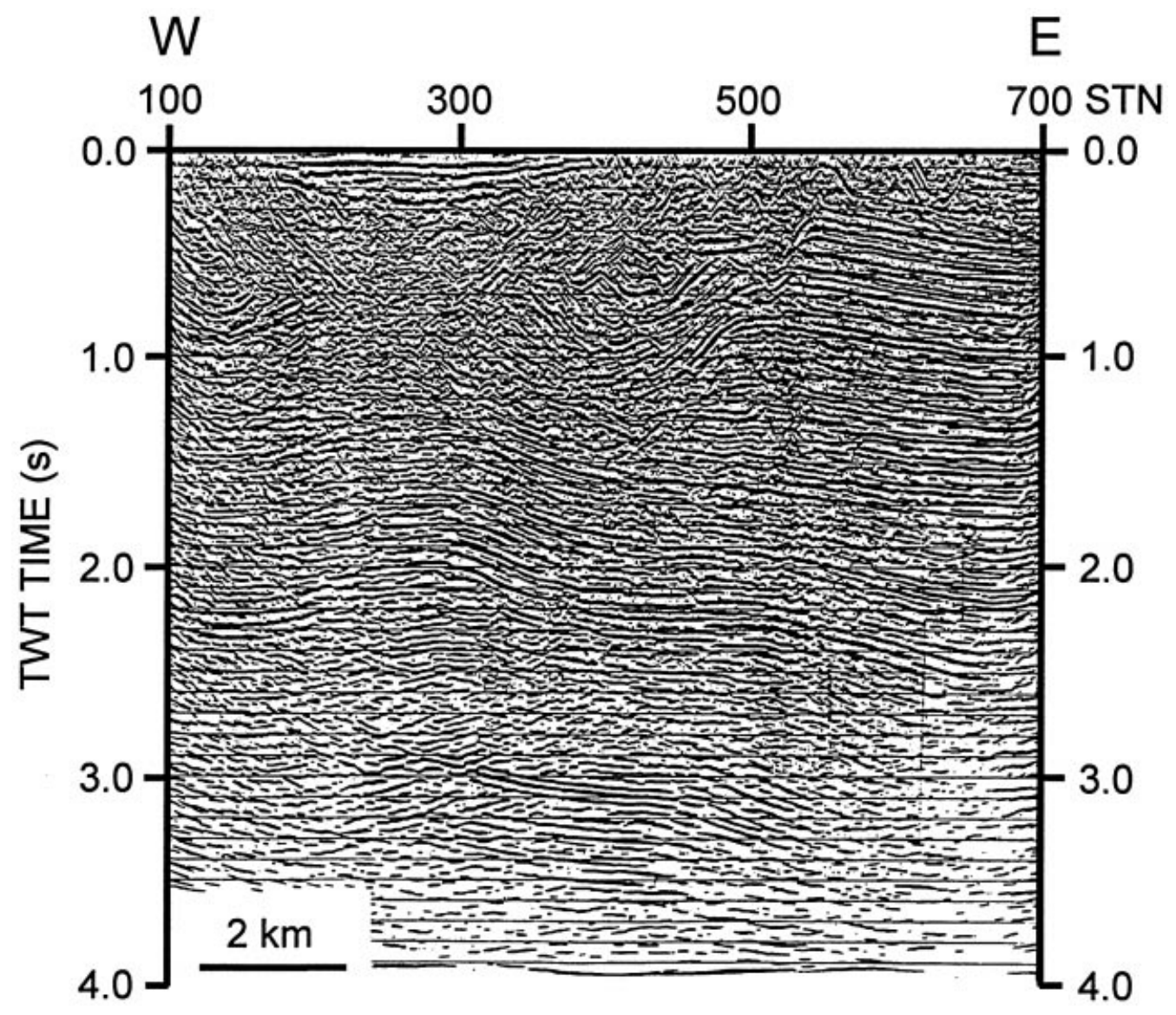

Figure 8. Migrated seismic reflection profile A88-142 across the Yallalie structure. The bowl-shaped zone of chaotic reflectors extends from the western end of the profile to about station 550. The displaced reflectors below station 500 are evidence of faulting during the formation of the structure. Note that continuous reflectors can be easily traced below the Yallalie structure. See Figure 1 for location.

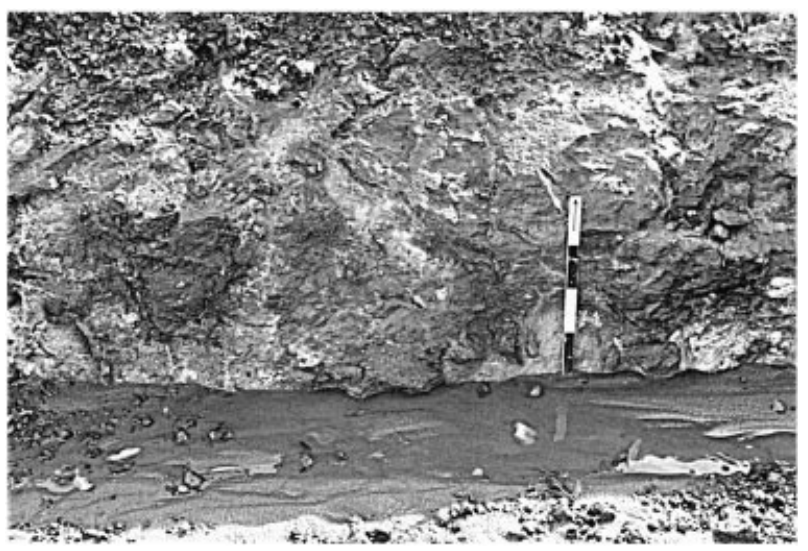

Figure 9. Allochthonous breccia outcropping in road cutting at Mungedar near the Yallalie structure (bars on scale $10 \mathrm{~cm}$ long). See Figure 1 for location.

the Agaton bores, and as scattered outcrops in the area around the Yallalie basin, do not appear outwardly to be deformed. However, significantly, the Coolyena Group is absent in the Yallalie-1 well (Fig. 3).

Owing to their deeply weathered nature, it was not possible to determine biostratigraphically the ages of

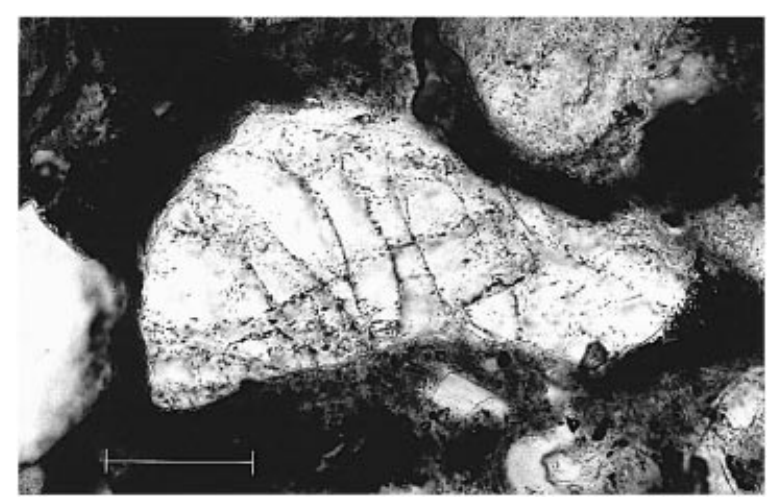

Figure 10. Photomicrograph of quartz grain in siltstone ( $365.76 \mathrm{~m}$ depth in the Agaton 1 bore) from the Yarragadee Formation in the Yallalie structure displaying incipient prismatic cleavage and irregular curved planes formed essentially by brittle fracture (ppl) (scale bar is $100 \mu \mathrm{m}$ ).

the rocks within the allochthonous breccia. However, the breccia deposit (see Figs 1, 9), is topographically (and possibly stratigraphically) lower than a gently dipping outcrop of the Gingin Chalk immediately to the west. In the Dandaragan Trough, the Coolyena Group contains two prominent glauconitic green- 
Table 3. INAA analyses of core samples from the Yallalie structure

\begin{tabular}{|c|c|c|c|c|}
\hline Weight $\dagger$ & Y-1200 & Y-1700 & Y-2010 & Y-2302 \\
\hline $\mathrm{Na}(\%)$ & 0.23 & 0.61 & 0.40 & 0.29 \\
\hline K (\%) & 1.65 & 4.25 & 2.18 & 1.89 \\
\hline $\mathrm{Sc}$ & 11.5 & 9.92 & 13.5 & 15.6 \\
\hline $\mathrm{Cr}$ & 65.2 & 68.3 & 77.3 & 90.9 \\
\hline $\mathrm{Fe}(\%)$ & 3.51 & 2.88 & 3.05 & 4.68 \\
\hline $\mathrm{Co}$ & 12.9 & 15.4 & 13.6 & 20.1 \\
\hline $\mathrm{Ni}$ & 5 & 5 & 10 & 8 \\
\hline $\mathrm{Zn}$ & 82 & 67 & 92 & 124 \\
\hline $\mathrm{Ga}$ & 23 & 18 & 23 & 31 \\
\hline As & 2.71 & 2.39 & 1.76 & 1.71 \\
\hline $\mathrm{Se}$ & 0.34 & 0.15 & 0.21 & 0.09 \\
\hline $\mathrm{Br}$ & 0.57 & 0.35 & 0.62 & 0.45 \\
\hline $\mathrm{Rb}$ & 82.6 & 149 & 111 & 116 \\
\hline $\mathrm{Sr}$ & 85 & 115 & 95 & 85 \\
\hline $\mathrm{Zr}$ & 280 & 760 & 382 & 270 \\
\hline $\mathrm{Ag}$ & $<0.1$ & $<0.15$ & $<0.06$ & $<0.06$ \\
\hline $\mathrm{Sb}$ & 0.26 & 0.14 & 0.15 & 0.21 \\
\hline Cs & 2.76 & 2.57 & 3.12 & 4.87 \\
\hline $\mathrm{Ba}$ & 420 & 940 & 560 & 390 \\
\hline $\mathrm{La}$ & 62.4 & 48.4 & 74.1 & 88.2 \\
\hline $\mathrm{Ce}$ & 111 & 82.1 & 125 & 142 \\
\hline $\mathrm{Nd}$ & 50.7 & 39.2 & 57.9 & 61.6 \\
\hline Sm & 8.39 & 6.79 & 10.2 & 12.2 \\
\hline $\mathrm{Eu}$ & 1.51 & 1.49 & 1.81 & 2.01 \\
\hline $\mathrm{Gd}$ & 5.9 & 5.2 & 5.97 & 6.9 \\
\hline $\mathrm{Tb}$ & 0.95 & 0.91 & 1.04 & 1.11 \\
\hline Dy & 5.5 & 5.7 & 6.4 & 6.8 \\
\hline $\operatorname{Tm}$ & 0.41 & 0.48 & 0.47 & 0.53 \\
\hline $\mathrm{Yb}$ & 2.59 & 3.71 & 2.98 & 3.08 \\
\hline $\mathrm{Lu}$ & 0.39 & 0.56 & 0.46 & 0.47 \\
\hline $\mathrm{Hf}$ & 6.24 & 23.3 & 8.09 & 3.91 \\
\hline $\mathrm{Ta}$ & 1.09 & 1.35 & 1.32 & 1.41 \\
\hline $\mathrm{W}$ & 15.2 & 0.67 & 1.27 & 1.62 \\
\hline $\mathrm{Ir}(\mathrm{ppb})$ & $<0.1$ & $<0.15$ & 0.05 & $<0.1$ \\
\hline $\mathrm{Au}(\mathrm{ppb})$ & 2.3 & 1.4 & 2.1 & 2.5 \\
\hline $\mathrm{Hg}$ & $<0.2$ & $<0.1$ & $<0.2$ & $<0.2$ \\
\hline Th & 23.8 & 25.2 & 29.8 & 23.3 \\
\hline $\mathrm{U}$ & 5.22 & 4.69 & 7.21 & 5.77 \\
\hline $\mathrm{K} / \mathrm{U}$ & 3161 & 9062 & 3024 & 3276 \\
\hline $\mathrm{Zr} / \mathrm{Hf}$ & 44.87 & 32.62 & 47.22 & 69.05 \\
\hline $\mathrm{La} / \mathrm{Th}$ & 2.62 & 1.92 & 2.49 & 3.79 \\
\hline $\mathrm{Hf} / \mathrm{Ta}$ & 5.72 & 17.26 & 6.13 & 2.77 \\
\hline $\mathrm{Th} / \mathrm{U}$ & 4.56 & 5.37 & 4.13 & 4.04 \\
\hline $\mathrm{LaN} / \mathrm{Yb}_{\mathrm{N}}$ & 16.28 & 8.82 & 16.80 & 19.35 \\
\hline $\mathrm{Eu} / \mathrm{Eu}^{*}{ }^{\mathrm{N}}$ & 0.656 & 0.766 & 0.709 & 0.669 \\
\hline
\end{tabular}

†ppm unless specified otherwise

sands, the Poison Hill Greensand and the Molecap Greensand that lie directly above and below, respectively, the distinctive Gingin Chalk. Other glauconitic rocks are known to occur; however, it is possible that the highly weathered, green-coloured rocks occurring abundantly in the allochthonous breccia represent the altered debris from one of these greensands. No chalk was observed in the exposures of the breccia that were examined, suggesting that the impact was prior to the deposition of the Gingin Chalk, although this requires confirmation. Overall, the stratigraphic and structural evidence suggests that the Yallalie structure may be Late Cretaceous in age.

The isolated occurrence of an as yet unnamed lacustrine deposit of Pliocene age in the Yallalie-1 well (M. Economo, unpub. report, Ampol Exploration Ltd, 1991) suggests that a lake-containing basin had

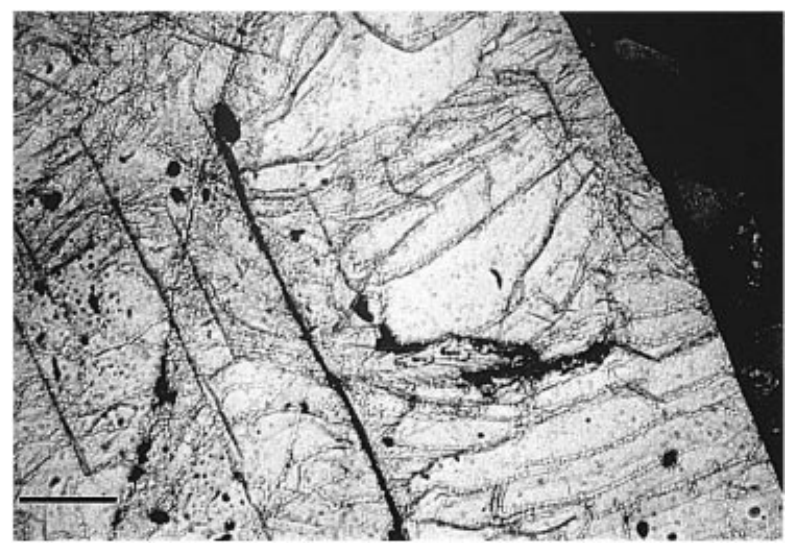

Figure 11. Photomicrograph of quartz grain from the Yarragadee Formation in the Yallalie-1 well, showing incipient prismatic cleavage (scale bar is $100 \mu \mathrm{m}$ ) (after K. B. McInerney, unpub. honours thesis Univ. Western Australia, 1991).

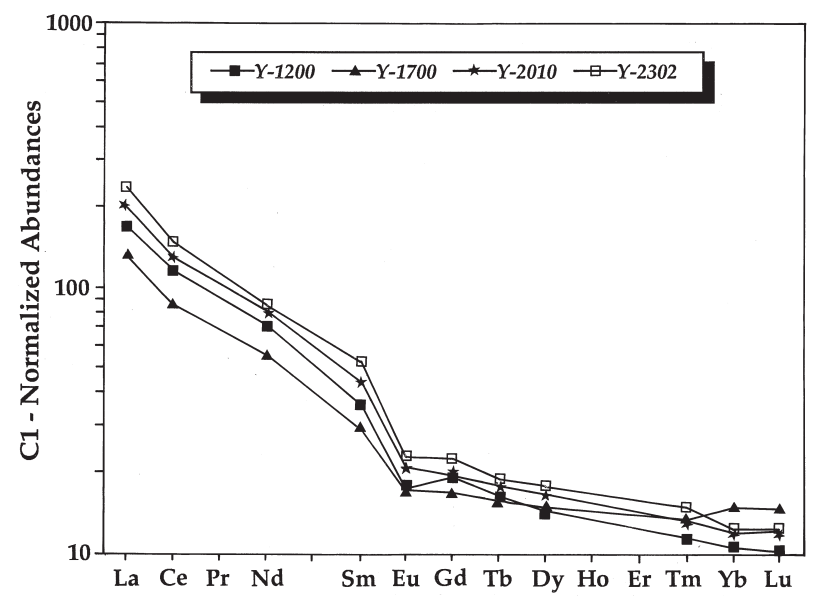

Figure 12. CI-normalized REE abundances in core samples from the Yallalie structure (see Table 2 for well identification). Normalization factors from Taylor and McLennan (1985).

developed over the Yallalie structure by that time. Extensive subsidence in the area of the basin, as indicated by the seismic profiles, appears to post-date the formation of the Yallalie structure, although slumping may have been dictated by structural elements within the zone of disturbed rocks below.

\section{Discussion}

The sub-surface morphology and style of deformation of the Yallalie structure determined from seismic data suggests strongly that it is of impact origin. However, conclusive evidence of intense shock-metamorphism that might have been expected to occur in the structure has not yet been recognized in either surface or core samples. Similarly, the chemistry of the target rocks analysed so far does not show any unequivocal 
signature of an impacting projectile. Two possibilities may account for this: (1) either the Yallalie structure is not of impact origin, or (2) the absence of these features is the result of a prolonged and complex postimpact history. Moreover, the location of the samples examined, combined with erosion, effectively preclude their exhibiting much in the way of impact related effects.

Plausible terrestrial mechanisms for the origin of the Yallalie structure are few. Crypto-explosive activity caused by volcanism is discounted, because of the absence of any evidence of igneous activity, either below or in the near vicinity of the structure, on geophysical data. Other possibilities include syn-sedimentary slumping or tectonic movements caused by faulting. The possibility of strong tectonic movements in the area is supported by the close juxtaposition of the structure to the Darling Fault. However, none of these mechanisms would account for the domed nature of the centrally uplifted region of the structure, or the localized nature of the disturbance. Diapirism could account for the uplift, although seismic profiles do not show any evidence for diapiric activity below the base of the structure.

If, however, the Yallalie structure is of impact origin, then it is possible that the apparent lack of impact melts and attendant intense shock-metamorphic features is the result of a combination of the nature of the original target rocks, and the amount of post-impact erosion suffered by the structure. In other recognized impact structures in the world, shock-metamorphic features are best developed in crystalline target rocks (Stöffler, 1971; Alexopoulos, Grieve \& Robertson, 1988). The poorly consolidated, interbedded porous sandstones and argillaceous sedimentary rocks of the Yallalie structure may have absorbed much of the energy of the impact event. Furthermore, from the extensive history of fluvial, lacustrine or shallowmarine deposition in the area, it is possible that the impact occurred subaqueously into a mixture of consolidated and partially consolidated sediments.

The geophysical data and stratigraphy of the structure indicate that it has been extensively eroded since formation, with perhaps more than one period of erosion occurring, and only the deeper levels are preserved. In the centrally uplifted region of the structure, stratigraphy indicates that the sediments have undergone structural uplift of approximately $700 \mathrm{~m}$. This uplift occurred during the formation of the structure. From a study of 24 complex terrestrial impact structures, Grieve \& Pilkington (1996) suggest that structural uplift (SU) is equal to $0.086 D^{1.03}$, where $D$ is the rim diameter of the impact structure. Applying the formula to the Yallalie structure yields a value for $\mathrm{SU}=c .1000 \mathrm{~m}$, which is in reasonable agreement with value of $700 \mathrm{~m}$ estimated from the stratigraphy. The difference could be accounted for by post-formational erosion of the structure that has removed the upper portion of the centrally uplifted region. The diameter of the central uplift (3-4 $\mathrm{km}$ ) is approximately one third of the overall diameter of the structure, and provides additional morphometric evidence of an impact origin (Therriault, Grieve \& Reimold, 1997).

\section{Summary and conclusions}

Conclusive petrographical or geochemical evidence of a meteorite impact origin for the Yallalie structure has proved elusive. To date, no evidence of the higher stages of shock-metamorphism has been found in any of the surface or sub-surface rocks from the area, and geochemical analyses of the target rocks do not show any significant noble metal anomalies. Notwithstanding, the absence of a plausible terrestrial explanation for the origin of the structure, the close similarity of the morphology of the zone of complex reflections to other described impact structures, and the presence of an allochthonous breccia deposit in what is otherwise an undisturbed sedimentary sequence strongly suggests that the Yallalie structure is of meteorite impact origin.

Perhaps the most important indication is provided by seismic reflection data, which clearly show continuity of stratigraphy below the Yallalie structure, suggesting its cause came from above rather than below. Geophysically, Yallalie is one of the most extensively studied potential impact structures in the world. A search for definitive evidence of shock-metamorphism in the rocks of the structure continues.

Acknowledgements. The authors thank Ampol Exploration (now Mobil Exploration and Producing Australia Pty Ltd.), and subsequently Carnarvon Petroleum, for generously allowing access to the Yallalie datasets. The Director of the Geological Survey of Western Australia is thanked for permission to sample the cores from the Agaton Borefield Project, and the Department of Land Administration (through A. Buchanan and R. Shaw) are thanked for satellite imagery. The late Eugene Shoemaker, and Carolyn Shoemaker, are thanked for assistance in the field and helpful discussions. Danielle West is thanked for the preparation of Figure 1. Richard Grieve and Victor Gostin provided constructive reviews and suggested many improvements to the manuscript. John Backhouse publishes with the permission of the Director, Geological Survey of Western Australia. This study was funded by an Australian Research Council small grant to M. C. Dentith and A. W. R. Bevan.

\section{References}

Alexopoulos, J. S., Grieve, R. A. F. \& Robertson, P. B. 1988. Microscopic deformation features in quartz: discriminative characteristics of shock-generated varieties. Geology, 16, 796-9.

Backhouse, J. 1984. Revised Late Jurassic and Early Cretaceous stratigraphy in the Perth Basin. Geological Survey of Western Australia Report 12, 1-6.

BACKhouse, J. 1988. Late Jurassic and Early Cretaceous palynology of the Perth Basin, Western Australia. Geological Survey of Western Australia Bulletin 135, $1-233$. 
Cockbain, A. E. 1990. Perth Basin. In Geology and Mineral Resources of Western Australia, pp. 514-16. Perth: Western Australia Geological Survey Memoir 3.

Dence, M. R., Grieve, R. A. F. \& Robertson, P. B. 1977. Terrestrial impact structures: principal characteristics and energy considerations. In Impact and Explosion Cratering (eds D. J. Roddy, R. O. Pepin and R. B. Merrill), pp. 247-75. New York: Pergamon Press.

Dentith, M. C., Bevan, A. W. R. \& McInerney, K. B. 1992. A preliminary investigation of the Yallalie Basin: a buried $15 \mathrm{~km}$ diameter structure of possible impact origin in the Perth Basin, Western Australia. Meteoritics 27, 214.

Drury, S. A. 1993. Image Interpretation in Geology, 2nd ed. London: Chapman \& Hall. 282 pp.

Glikson, A. Y. 1996. A compendium of Australian impact structures, possible impact structures, and ejecta occurrences. AGSO Journal of Australian Geology \& Geophysics 16, 373-5.

Grieve, R. A. F. 1991. Terrestrial impact: the record in the rocks. Meteoritics 26, 175-94.

Grieve, R. A. F. \& Pilkington, M. 1996. The signature of terrestrial impacts. AGSO Journal of Australian Geology \& Geophysics 16, 399-420.

Grieve, R. A. F., Robertson, P. B. \& Dence, M. R. 1981. Constraints on the formation of ring impact structures based on terrestrial data. In Multi-Ring Basins (eds P. H. Schultz and R. B. Merrill), pp. 37-57. New York: Pergamon Press.

Helby, R., Morgan, R. \& Partridge, A. D. 1987. A palynological zonation of the Australian Mesozoic. Association of Australasian Palaeontologists, Memoir 4, 1-94.

Hocking, R. M., Moors, H. T. \& van de GraAfF, W. J. E. 1987. Geology of the Carnarvon Basin, Western Australia. Geological Survey of Western Australia Bulletin 133, 1-289.

HöRz, F. 1982. Ejecta of the Ries crater, Germany. In Geological Implications of Impacts of Large Asteroids and Comets on the Earth (eds L. T. Silver and P. H. Schultz), pp. 39-55. Boulder: Geological Society of America Special Paper 190.

Hörz, F., Ostertag, R., \& Rainey, D. A. 1983. Bunte breccia of the Ries: Continuous deposits of large impact craters. Reviews of Geophysics and Space Physics 21, 1667-725.
Koeberl, C. 1993. Instrumental neutron activation analysis of geochemical and cosmochemical samples: a fast and reliable method for small sample analysis. Journal of Radioanalytical and Nuclear Chemistry 168, 47-60.

Koeberl, C. \& Anderson, R. R. 1996. Manson and company: impact structures in the United States. Geological Society of America Special Paper 302, 1-29.

Melosh, H. J. 1989. Impact Cratering: a Geologic Process. Oxford: Oxford University Press, $245 \mathrm{pp}$.

PASSMORE, J. R. 1969. Exploratory Drilling - Agaton Project, Watheroo Area Preliminary Report. Geological Survey of Western Australia Annual Report 1968, 12-14.

Pilkington, M. \& Grieve, R. A. F. 1992. The geophysical signature of terrestrial impact craters. Reviews of Geophysics 30, 161-81.

Playford, P. E., Cockbain, A. E. \& Low, G. H. 1976. Geology of the Perth Basin Western Australia. Geological Survey of Western Australia Bulletin 124, $1-311$.

Shoemaker, E. M. 1960. Penetration mechanics of high velocity meteorites, illustrated by Meteor Crater, Arizona. Proceedings of the 21st International Geological Congress, Copenhagen 18, 418-34.

Shoemaker, E. M. \& Shoemaker, C. S. 1988. Impact structures of Australia. Lunar and Planetary Science Conference XIX, 1079-80.

Spring, D. E. \& Newell, N. A. 1993. Depositional systems and sequence stratigraphy of the Cretaceous Warnbro Group, Vlaming Sub-basin, Western Australia. APEA Journal 33, 190-204.

STÖFfLER, D. 1971. Progressive metamorphism and classification of shocked and brecciated crystalline rocks in impact craters. Journal of Geophysical Research 76, 5541-51.

STÖFFleR, D. \& LANGENHORST, F. 1994. Shock metamorphism of quartz in nature and experiment. I. Basic observations and theory. Meteoritics 29, 155-81.

TAYlor, S. R. \& McLennAn, S. M. 1985. The Continental Crust: its Composition and Evolution. Oxford: Blackwell Scientific Publications, 312 pp.

Therriault, A. M., Grieve, R. A. F. \& Reimold, W. U. 1997. Original size of the Vredefort structure: implications for the geological evolution of the Witwatersrand Basin. Meteoritics \& Planetary Science 32, 71-7. 